\title{
Gluconic Acid-producing Bacteria from Honey Bees and Ripening Honey
}

\author{
By T. RUIZ-ARGÜESO AND A. RODRIGUEZ-NAVARRO \\ Departamento de Microbiología, Escuela Técnica Superior de \\ Ingenieros Agrónomos, Universidad Politécnica, Madrid-3, Spain
}

(Received I7 November I97I ; revised 20 December 1972)

\section{SUMMARY}

Gluconic acid-producing bacteria have been isolated in high glucose media from honey bees and from ripening honey. Their morphological and biochemical properties indicate possible relationship with acetic bacteria and certain pseudomonads. At least part of the gluconic acid in honey may arise from the metabolic activity of these bacteria.

\section{INTRODUCTION}

Several apparently non-pathogenic bacterial groups have been isolated from bees (Bailey, I968), some of them being implicated in the normal biochemical transformations occurring in the bee-hives (Pain \& Maugenet, 1966; Rodriguez-Navarro \& Ruiz-Argüeso, 1970).

We have regularly detected bacteria producing gluconic acid in healthy bees and ripening honey. This paper reports the characterization of these organisms and their relationship to other gluconic acid bacteria.

\section{METHODS}

Bees and honey. Bees and honey samples were taken from several apiaries in the Madrid area.

Media and conditions. The medium referred to as 'basal' was a broth of yeast extract (Oxoid) $0.6 \%(\mathrm{w} / \mathrm{v})$. Yeast glucose broth was basal medium with $5 \%$ glucose; it was solidified when required with $1 \cdot 5 \%$ agar. Chalk glucose agar was a yeast glucose agar with $\mathrm{I} \%$ sterile $\mathrm{CACO}_{3}$. Incubation was $30{ }^{\circ} \mathrm{C}$ unless otherwise specified.

Isolations. Samples of ripening honey, larvae, bees, and bee-intestinal contents were streaked on chalk-glucose agar, either directly or after incubation in yeast glucose broth until the $\mathrm{pH}$ value fell below 3. Colonies surrounded by clear zones of dissolved $\mathrm{CaCO}_{3}$ after 4 or 5 days were transferred to yeast glucose agar slants and purified. Maintenance by subculturing every 2 weeks proved to be necessary.

Counting procedures. Intact intestines and rest of the bee's body were ground separately in sterile water previous to inoculation. Honey samples were dissolved in sterile water.

The most probable number (m.p.n.) was obtained from quintuplicate tubes of $10 \mathrm{ml}$ basal medium with $10 \%(\mathrm{w} / \mathrm{v})$ glucose inoculated with dilutions covering a threefold decimal range $(\mathrm{O} \cdot \mathrm{I}, \mathrm{I} \cdot \mathrm{O}$, and $\mathrm{IO} \mathrm{ml})$ in water. Double strength medium was used for the $\mathrm{IO} \mathrm{ml}$ inoculum. M.p.m. were read from probability tables. No significant differences were obtained in m.p.n. when $40 \%$ (w/v) sucrose was used for dilutions instead of water. $\mathrm{Na}$ Penicillin $\mathrm{G}(3 \mu \mathrm{g} / \mathrm{ml})$ was used in some countings.

Culture tubes with a $\mathrm{pH}$ of 3 or below after Io days of incubation were recorded as 
positive for counting purposes, since gluconic acid bacteria were always identified in these tubes. These bacteria could not be isolated from tubes with $\mathrm{pH}$ values above 3 (recorded as negative), even though microbial growth was occasionally observed.

Identification. Procedures recommended by the Society of American Bacteriologists (I957) were essentially followed, except that basal medium was used instead of nutrient broth; $\mathrm{pH}$ was adjusted with $\mathrm{HCl}$.

Carbohydrate dissimilation was investigated in basal medium plus $5 \%$ filter-sterilized sugar and bromocresol purple as indicator. Hugh \& Leifson (I953) test for glucose was also performed.

Ethanol oxidation was tested by the agar plate procedure of Shimwell, Carr \& Rhodes ( 1960$)$, in liquid basal medium with $2 \%(\mathrm{v} / \mathrm{v})$ ethanol, and in the same medium plus glucose $(5 \%, w / v)$. Ethanol losses due to evaporation were determined in control flasks without inoculation.

Ketogenic activity from glycerol, mannitol and sorbitol was determined by the agar plate procedure of Shimwell et al. (1960) and also in a basal medium to which $3 \%$ glycerol, $5 \%$ mannitol or $5 \%$ sorbitol was added. Broths were observed for growth and reducing substances with Fehling's solution after Io days.

Gluconate oxidation was investigated according to Haynes (I95I).

All the foregoing determinations in liquid media were performed at $\mathrm{pH}$ values of 4 and 7 , with shaken as well as in stationary culture.

Production from D-glucose and D-fructose of substances giving positive reaction with ferric chloride was tested by the method of Asai \& Shoda (I958).

Lactate and acetate oxidation tests were performed according to Shimwell et al. (I960) and in liquid basal medium plus $3 \%$ potassium lactate or acetate with bromothymol blue as indicator; $\mathrm{pH}$ values were adjusted to 6.4 prior to inoculation. After 20 days, broths were observed for growth and acid production.

Oxidase test was performed by Kovacs's method (I956).

Gelatin hydrolysis was observed on plates of yeast glucose agar with $0.4 \%$ gelatin (Frazier, 1926).

Flagella were stained by Leifson's procedure (Skerman, I967) for light-microscope examination and by negative staining with phosphotungstic acid for electron microscope preparations.

Acid production from glucose was tested up to $50 \%(\mathrm{w} / \mathrm{v})$, the maximum allowing growth, in basal liquid medium shaken at $30{ }^{\circ} \mathrm{C}$. Samples were taken at 3,6 and 1o days and acid was measured according to Association of Official Agricultural Chemists (1970), as specified for honey. Production of acid from glucose at concentration inhibitory to bacterial growth was detected on yeast agar plates containing the required glucose concentration and $2 \%$ chalk; a clear zone due to solution of $\mathrm{CaCO}_{3}$ round the implanted bacterial masses was recorded as positive.

Chemical analyses. Glucose and ethanol were determined as described by Neish (I952). Sugar acids were identified by paper chromatography with the following solvent systems (Gordon, Thornburg \& Werum, I962): isobutanol + pyridine + water + glacial acetic acid (12:6:4:I) and isopropanol + pyridine + water + glacial acetic acid $(8: 8: 4: 1)$. Spots on chromatograms were developed with aniline oxalate (Horrocks \& Manning, 1949) or ammoniacal silver nitrate (Hulme, I96I). 
Table I. Results of biochemical tests on gluconic acid-producing bacteria

$\begin{array}{lclc}\text { Acid from glucose } & + & \text { Litmus milk } & \text { Unchanged } \\ \text { Acid from sucrose } & + & \text { Ethanol oxidation } & - \\ \text { Acid from lactose } & - & \text { Lactate oxidation } & - \\ \text { Acid from arabinose } & + & \text { Acetate oxidation } & - \\ \text { Acid from xylose } & + & \text { Growth at pH 3 } & + \\ \text { Catalase } & + & \text { Reaction with } \mathrm{FeCl}_{3} & - \\ \text { Oxidase } & - & \text { Ketogenic activity from: } & + \\ \text { Gelatin hydrolysis } & - & \text { Glyerol } & * \\ \text { Nitrate reduction } & - & \text { Mannitol } & + \\ \text { Voges-Proskauer test } & + & \text { Sorbitol } & + \\ & & \text { Gluconate } & +\end{array}$

* Type II bacteria were positive, Type I bacteria were negative.

Table 2. Effect of glucose concentration on acid production by honey bacteria

\begin{tabular}{|c|c|c|c|c|c|c|}
\hline \multirow{3}{*}{$\begin{array}{c}\text { Glucose } \\
\text { concentration } \\
(\%, w / v)\end{array}$} & \multicolumn{6}{|c|}{ m-equiv. acid/l after incubation } \\
\hline & \multicolumn{2}{|c|}{3 days } & \multicolumn{2}{|c|}{6 days } & \multicolumn{2}{|c|}{ Io days } \\
\hline & A & B & A & B & A & B \\
\hline 5 & 100 & 20 & IIO & 30 & 120 & 30 \\
\hline 10 & 100 & 50 & 120 & 100 & 120 & 110 \\
\hline 15 & I 30 & 60 & 160 & IIO & 160 & IIO \\
\hline 20 & 100 & 40 & 180 & 200 & 180 & 220 \\
\hline 30 & 90 & 30 & 210 & 180 & 220 & 230 \\
\hline 40 & 70 & 30 & 200 & 170 & 210 & 180 \\
\hline 50 & 30 & 30 & 150 & 100 & 170 & 170 \\
\hline
\end{tabular}

A, Type I bacteria; B, Type II bacteria. For further details see text.

RESULTS

Morphological and cultural characteristics. Two different types of gluconic acidproducing bacteria from honey could be distinguished on the bases of morphological and cultural characteristics. Type I bacteria were long bacilli (IO to $20 \mu \mathrm{m}$ ) occurring singly or in pairs, forming white undulate irregular colonies on yeast glucose and flocculent growth with slight pellicle or islets with a completely clear medium in glucose yeast broth. The second type of bacterium encountered (Type II) were spindle rods $(2.5 \times \mathrm{I} \mu \mathrm{m})$, forming white entire circular colonies on yeast glucose agar and homogeneous turbidity in yeast glucose broth. Both types were Gram-negative and had polar flagella. Optimum temperature for growth was $30^{\circ} \mathrm{C}$; no growth occurred above $40{ }^{\circ} \mathrm{C}$; minimum growth temperature was below $15{ }^{\circ} \mathrm{C}$.

Physiological characteristics. These are listed in Table I. The aerobic habit of these organisms and their oxidative utilization of glucose was confirmed by Hugh and Leifson's method.

Broths inoculated with these bacteria reached $\mathrm{pH}$ values below 3 after 5 to Io days of incubation.

Acid production at different glucose concentrations is recorded in Table 2. No significant decrease in acid production was observed even at $40 \%$ and $50 \%(\mathrm{w} / \mathrm{v})$ sugar, which markedly limited growth. Sugar at $50 \%$ and $60 \%(\mathrm{w} / \mathrm{w})$ did not support growth but allowed acid production in agar media as previously described.

Gluconic acid was the main acid produced in liquid media according to co-chromatography 


\section{Table 3. Comparison of honey bacteria with related genera*}

\begin{tabular}{|c|c|c|c|c|}
\hline & $\begin{array}{c}\text { Honey } \\
\text { bacteria }\end{array}$ & Acetobacter & $\begin{array}{l}\text { Gluconobacte } \\
\text { (Acetomonas) }\end{array}$ & Pseudomonas \\
\hline Ethanol oxidation & - & + & ++ & $-\ddagger$ \\
\hline Acetate oxidation & - & + & - & \pm \\
\hline Acetate oxidation & - & + & - & $\overrightarrow{+}$ \\
\hline Growth at $\mathrm{pH} 4.5$ & - & + & + & - \\
\hline Dihydroxyketone from glycerol & \pm & \pm & + & - \\
\hline Flagellation (if motile) & Polar & Peritrichous & Polar & Polar \\
\hline
\end{tabular}

with an authentic sample: 2-ketogluconic acid was barely detected in chromatograms. Neither 5-ketogluconic acid nor volatile acids were found.

Growth with ethanol did not occur either on Shimwell's agar or in liquid basal medium with $2 \%(\mathrm{v} / \mathrm{v})$ ethanol at $\mathrm{pH} 4$ or 7 . In yeast glucose broth plus ethanol, growth but not ethanol utilization was observed.

The bacteria did not grow in a basal medium with glucose below $2 \%(w / v)$.

Incidence of gluconic acid bacteria in the beehive. Over 100 individual bees were examined during the flowering season. Gluconic bacteria appeared as frequently in the bee-intestines as in the rest of the bee's body, average total count/individual (from m.p.n. values) was $8 \times 10^{3}$, with extreme values at $4 \times 10^{3}$ and $5 \times 10^{5}$. Addition of $\mathrm{Na}$ Penicillin $\mathrm{G}$ to inhibit growth of Gram-positive intestinal bacteria did not significantly alter results, so it was omitted in further tests.

In ripening honey, samples of increasing density gave counts decreasing from $10^{4}$ to 0 .

No gluconic acid bacteria could be isolated from honey sealed in honey comb or from larvae.

\section{DISCUSSION}

The most relevant differential properties of the gluconic acid-producing bacteria from honey and the bacterial groups to which they might belong are presented in Table 3.

It appears that these Gram-negative, polar flagellated bacteria, producing large amounts of gluconic acid from glucose, capable of growth at $\mathrm{pH}_{3}$ but unable to utilize ethanol, could be included in the subgenus Eugluconobacter of the genus Glu conobacter (Asai, 1935).

This highly controversial genus was initially described by Asai as a subgroup of acetic acid bacteria with scarce or no acetifying capacity. Later Leifson (I954) regrouped the same bacteria according to their flagellation and metabolism and described the genus Acetomonas, that included those gluconobacters that oxidized ethanol (Asai, I935). Shimwell \& Carr (1959) rejected the genus Gluconobacter, considering that the genus included both Acetomonas and Pseudomonas strains.

However, we think that inability to oxidize ethanol should not exclude a bacterial strain from the genus Gluconobacter if it can grow in strongly acid media. Pseudomonas species in contrast are adapted to neutral or slightly alkaline environments (Kluyver \& van Niel, 1936; Stanier, 1947). We concur with the opinion of Komagata (1970) that growth at $\mathrm{pH}_{3}$ rather than 4.5 is more adequate for taxonomic differentiation between Gluconobacter and Pseudomonas. 
Thus the honey gluconic bacteria can be included in the genus Gluconobacter, as originally defined by Asai (1935), as redefined by Asai \& Shoda (1958) and even, in the sense finally proposed by Lott \& Carr (I964), restricted to bacteria with properties similar to acetic acid bacteria but unable to acetify ethanol.

Stinson, Subers, Petty \& White (1960) established that gluconic was the main acid found in clover honey. Bee-gland enzymes are generally considered responsible for gluconic acid synthesis (Shepartz \& Subers, I964; Louveaux, I968). However, the high number of gluconic acid bacteria present in honey during the ripening stage and their ability to produce large amounts of gluconic acid at high glucose concentrations and aeration suggests that at least part of the gluconic acid present in honey has a bacterial origin.

\section{REFERENCES}

Asal, T. (I935). Taxonomic studies of acetic acid bacteria and allied oxidative bacteria in fruits and a new classification of oxidative bacteria. Journal of the Agricultural Chemical Society of Japan II, 686-696.

AsAI, T. \& SHODA, K. (1958). The taxonomy of Acetobacter and allied oxidative bacteria. Journal of General and Applied Microbiology 4, 289-3I I.

Association of Official Agricultural Chemists ( 1970). In Official Methods of Analysis, i ith ed.. pp. 548549. Edited by William Horwith. Washington: AOAC.

BaIley, L. (I968). Honey bee pathology. Annual Review of Entomology 13, I9I-2 I 2.

DE LEY, J. (1960). Comparative carbohydrate metabolism and localization of enzymes in Pseudomonas and related micro-organisms. Journal of Applied Bacteriology 23, 400-44I.

Frazier, W. H. (1926). A method for the detection of changes in gelatin due to bacteria. Journal of Infectious Diseases 39, 302-309.

Gordon, H. T., Thornburg, W. W. \& Werum, L. N. (1962). Rapid paper chromatographic fractionation of complex mixtures of water-soluble substances. Journal of Chromatography 9, 44-59.

Haynes, W. C. (195I). Pseudomonas aeruginosa - its characterization and identification. Journal of General Microbiology 5, 939-950.

Horrocks, R. H. \& Manning, G. B. (1949). Partition chromatography on paper. Identification of reducing substances in urine. Lancet 256, $1042-1045$.

Hugh, R. \& Leifson, E. (1953). The taxonomic significance of fermentations versus oxidative metabolism of carbohydrates by various Gram-negative bacteria. Journal of Bacteriology 66, 24-26.

Hulme, A. C. (196I). Methods for the determination of organic acid. In Advances in Applied Microbiology, vol. 3, pp. 343-39I. Edited by W. Umbreit. New York and London: Academic Press.

Kluyver, A. J. \& van Niel, C. B. (1936). Prospects for a natural system of classification of bacteria. Zentralblatt für Bakteriologie, Parasitenkunde, Infektionskranheiten und Hygiene (Abteilung II) 94, $369-403$.

Komagata, K. (1970). In Culture Collections of Microroganisms, Proceedings of the International Conference on Culture Collections, Tokyo, 7-I I Oct. I968, p. 560. Edited by H. Iizuka and T. Hasegawa. Baltimore, Maryland and Manchester, England: University Park Press.

Kovacs, N. (1956). Identification of Pseudomonas aeruginosa by the oxidase reaction. Nature, London $\mathbf{1 7 8}$, 703 .

Leifson, E. (1954). The flagellation and taxonomy of species of Acetobacter. Antonie van Leeuwenhoek 20, IO2-IIO.

LotT, A. F. \& CARR, J. G. (1964). Characteristics of an organism causing spoilage in an orange juice beverage. Journal of Applied Bacteriology 27, 379-384.

Louveaux, J. (I968). Composition, proprietés et technologie du miel. In Traité de Biologie de l'Abeille, vol. 3, pp. 277-324. Paris: Masson.

NeISH, A. C. (1952). Analytical Methods for Bacterial Fermentations. Report no. 46-8-3 (Second revision). Saskatoon: National Research Council of Canada.

Pain, J. \& MaUgenet, J. (1966). Recherches biochimiques et physiologiques sur le pollen emmagasiné par les abeilles. Annual de l'Abeille 9, 209-236.

Rodriguez-Navarro, A. \& Ruiz-Argüeso, T. (1970). Ripening honey bacteria. Lebensmittel-Wissenschaft und Technologie $3(6)$, I 18. 
Schepartz, A. I. \& Subers, M. H. (I964). The glucose oxidase of honey. I. Purification and some general properties of the enzyme. Biochimica et biophysica acta 85, 228-237.

Shimwell, J. L. \& Carr, J. G. (1959). The genus Acetomoas. Antonie van Leeuwenhoek 25, 353-400.

Shimwell, J. L. \& CARR, J. G. (1960). Support for differentiation of Acetobacter and Acetomonas. Antonie van Leeluwemhoek 26, 430-432.

Shimwell, J. L., CARR, J. G. \& Rhodes, M. E. (1960). Differentiation of Acetomonas and Pseudomonas. Journal of General Microbiology 23, 283-286.

Skerman, V. B. D. (1967). Leifson's flagella stain. In A Guide to the Identification of the Genera of Bacteria, 2nd ed., pp. 277-278. Baltimore: Williams and Wilkins.

SOCIETY OF AMERICAN BACTERIOLOGISTS. (1957). Manual of Microbiological Methods. New York, Toronto and London: McGraw-Hill.

Stanier, R. Y. (1947). Acetic acid production from ethanol by fluorescent pseudomonads. Journal of Bacteriology 54, 191-194.

Stinson, E. B., Subers, M. H., Petty, J. \& White, J. W. Jun (I960). The composition of honey. V. Separation and identification of the organic acids. Archives of Biochemistry and Biophysics 89, 6-I 2. 